\title{
Structural-, Kinetic- and Docking Studies of Artificial Imine Reductases Based on the Biotin-Streptavidin Technology: An Induced Lock-and-Key Hypothesis
}

Victor Muñoz Robles, ${ }^{a,}{ }^{\vee}$ Marc Dürrenberger, ${ }^{b,}{ }^{\vee}$ Tillmann Heinisch, ${ }^{c}$ Agustí Lledós, ${ }^{a}$ Tilman Schirmer, ${ }^{c}$ Thomas R. Ward ${ }^{b, *}$ and Jean-Didier Maréchal ${ }^{a, *}$

Received (in $X X X, X X X)$ Xth $X X X X X X X X X 20 X X$, Accepted Xth $X X X X X X X X X 20 X X$

DOI: $10.1039 / b 000000 x$

\section{$\underline{\text { Supplementary information }}$}

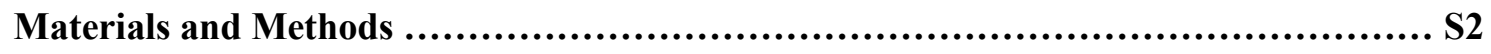

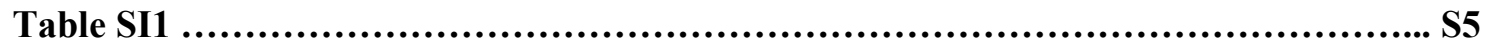

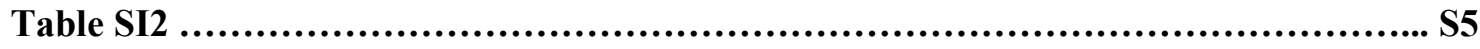

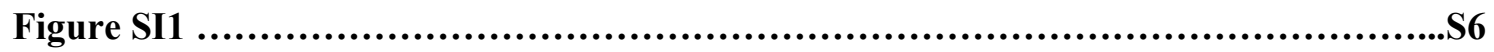

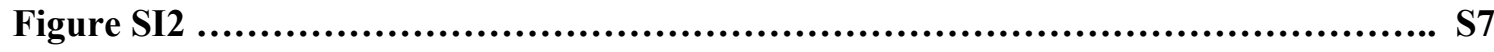

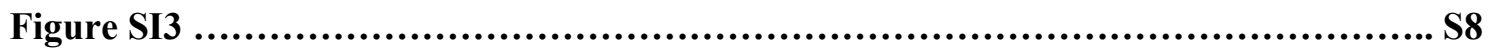

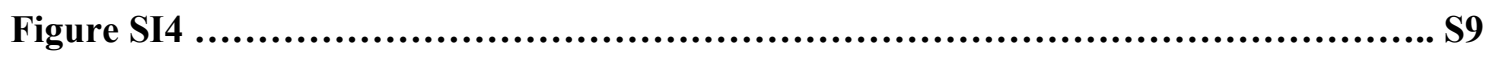

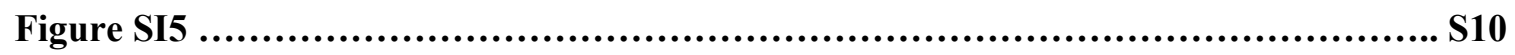

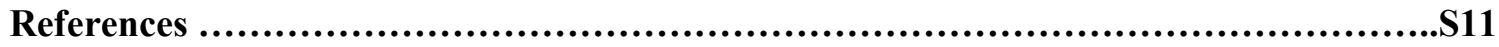




\section{Materials and Methods}

\section{Michaelis Menten Kinetics General Considerations}

6,7-dimethoxy-1-methyl-3,4-dihydroisoquinoline 1 was purchased from Acros and used as received. Streptavidin (Sav) mutants were produced, purified and characterized as previously described. ${ }^{1}$ The Sav used in this work and on which all variants were based is the T7-tagged core Sav described by Gallizia et al. ${ }^{2}$ (referred to as WT Sav). For a detailed synthesis of $\left[\mathrm{Cp} * \operatorname{Ir}\left(\right.\right.$ Biot- $p$-L)Cl], see reference. ${ }^{3}$ HPLC measurements were performed on Agilent instruments equipped with modules from the 1100 and 1200 series and diode array detectors.

\section{Stock solutions and buffers MOPS/formate buffer}

$5.0225 \mathrm{~g}$ of 3-( $\mathrm{N}$-morpholino)propanesulfonic acid (MOPS) and $8.1612 \mathrm{~g}$ of sodium formate were dissolved in $40 \mathrm{ml}$ water and the $\mathrm{pH}$ was adjusted by addition of $\mathrm{NaOH}$ (final concentration: $0.6 \mathrm{M}$ MOPS, $3 \mathrm{M}$ formate).

\section{[Cp*Ir(Biot-p-L)Cl)]}

$[\mathrm{Cp} * \operatorname{Ir}($ biot $-p-\mathrm{L}) \mathrm{Cl})]$ was dissolved in degassed DMF to a final concentration of $10,20,30$, or $40 \mathrm{mM}$, respectively. These solutions were stored under nitrogen at $4{ }^{\circ} \mathrm{C}$ and used within 5 days.

\section{Substrate}

6,7-dimethoxy-1-methyl-3,4-dihydroisoquinoline $1(410.5 \mathrm{mg})$, MOPS (251.12 mg) and sodium formate (408.1 mg) were dissolved in $2 \mathrm{ml}$ water in a volumetric flask and the $\mathrm{pH}$ was adjusted by addition of concentrated sulfuric acid (final concentrations: 1 M 6,7-dimethoxy-1-methyl-3,4-dihydroisoquinoline 1, 0.6 M MOPS, 3 M formate).

\section{ATHase}

Sav mutants were weighted into $2 \mathrm{~mL}$ PP-tubes and dissolved in the MOPS/formate buffer to a concentration of $200 \mathrm{mM}$ streptavidin free biotin binding sites (the average of free binding sites per Sav tetramer was determined with a biotin-4fluorescein assay). ${ }^{4}$ An appropriate volume of the corresponding $\left.[\mathrm{Cp} * \operatorname{Ir}(\operatorname{Biot}-p-\mathrm{L}) \mathrm{Cl})\right]$ stock solution was added $(5 \mu \mathrm{L} / \mathrm{ml})$ in order to adjust the desired $[\mathrm{Ir}] / \mathrm{Sav}$ biotin binding sites ratio and the mixture was vigorously vortexed.

\section{General procedure}

For an individual kinetic measurement at a particular substrate concentration, $100 \mu \mathrm{l}$ of the ATHase stock solution was added to a glass tube equipped with a mechanical stirrer and MOPS/formate buffer was added to adjust the final volume of $200 \mu \mathrm{L}$ (between $0-95 \mu \mathrm{L}$ ). The reaction was initiated by adding an appropriate volume of the substrate stock solution (between 5-100 $\mu \mathrm{l}$ ) and the mixture was stirred at $25^{\circ} \mathrm{C}$ (final concentrations: $99.5 \mu \mathrm{M}$ Sav biotin binding sites, between 24.88 and $99.5 \mu \mathrm{M}[\mathrm{Cp} * \operatorname{Ir}($ biot $-p-\mathrm{L}) \mathrm{Cl})]$ ). Aliquots of $50 \mu 1$ were collected at 15,30 and 45 minutes and were added to PP-tubes containing $40 \mu \mathrm{l}$ of a freshly prepared glutathione solution $(250 \mathrm{mM})$ which was found to be an effective inhibitor of the catalyst. Water $(300 \mu \mathrm{l})$ was added and $200 \mu \mathrm{l}$ of the resulting solution was further diluted with water (500 $\mu 1)$ before analysis by RP-HPLC using an Eclipse XDB-C18 column $\left(5 \mu \mathrm{m}, 4.6 \times 150 \mathrm{~mm}\right.$, Agilent); solvent A: $\mathrm{H}_{2} \mathrm{O}$ with $0.1 \%$ TFA, solvent $\mathrm{B}$ : $\mathrm{MeOH}$ with $0.1 \% \mathrm{TFA} ; 87.5 \% \mathrm{~B}$ at $0 \mathrm{~min}, 87.5 \% \mathrm{~B}$ at $20 \mathrm{~min}, 60 \% \mathrm{~B}$ at $21.5 \mathrm{~min}, 60 \% \mathrm{~B}$ at $23.5 \mathrm{~min}, 12.5 \% \mathrm{~B}$ at $25 \mathrm{~min}, 12.5 \% \mathrm{~B}$ at $30 \mathrm{~min} ; 1 \mathrm{ml} / \mathrm{min} ; 25^{\circ} \mathrm{C}, 280 \mathrm{~nm} ; \mathrm{T}_{\mathrm{R}} 12.3 \mathrm{~min}$ (6,7-dimethoxy-1-methyl1,2,3,4-tetrahydroisoquinoline), $16.4 \mathrm{~min}$ (6,7-dimethoxy-1-methyl-3,4-dihydroisoquinoline).

For a given Sav mutant at a given [Ir]/Sav biotin binding sites ratio, the kinetic measurements using different substrate concentrations (between 25 and $500 \mathrm{mM}$ ) were performed simultaneously by starting the reactions staggered every minute. All measurements were performed in triplicate.

Product concentrations were determined under consideration of the response factor and plotted against the corresponding reaction times (see above). Initial rates at a given initial substrate concentration were obtained by linear regression of the resulting data points. The average value of these rates was plotted as a function of the substrate concentration. The apparent Michaelis-Menten parameters $V_{\max }, K_{\mathrm{m}}$ and $K_{\mathrm{i}}$ were obtained applying nonlinear regression (least squares method) using GraphPad Prism 5.0 ${ }^{\circledR}$ corresponding to the Michaelis-Menten equation ${ }^{5}$ or to Haldane's equation for substrate inhibition. ${ }^{6}$

\section{Determination of the enantioselectivity}

For a given Sav mutant at a given [Ir]:Sav biotin binding sites ratio, reactions were set up as described above at a particular substrate concentration and run for 7 hours at $25^{\circ} \mathrm{C}$ before water was added $(500 \mu l)$ followed by $50 \mu l$ of a $20 \% \mathrm{NaOH}$ solution. The mixture was extracted two times with dichloromethane $(1 \mathrm{ml})$, the combined organic fractions dried over anhydrous sodium sulfate, filtered and analysed by chiral HPLC using a Chiralpak IC column (5 $\square \mathrm{m}, 4.6 \mathrm{~mm}$. 
$25 \mathrm{~mm}$ ) and dichloromethane containing $1 \%$ isopropanol and $0.06 \%$ diethylamine as an eluent; $1 \mathrm{ml} / \mathrm{min} ; 25{ }^{\circ} \mathrm{C}, 280 \mathrm{~nm}$, $\mathrm{T}_{\mathrm{R}} 8.6 \mathrm{~min}((S)$ - 6,7-dimethoxy-1-methyl-1,2,3,4-tetrahydroisoquinoline 2), 9.5 min (6,7-dimethoxy-1-methyl-3,4dihydroisoquinoline 1), $15.6((R)-6,7$-dimethoxy-1-methyl-1,2,3,4-tetrahydroisoquinoline 2, referred to as salsolidine).

\section{HABA Displacement titration for the estimation of the $K_{a}$ of $\left[\mathrm{Cp} * \operatorname{Ir}(\text { biot-p-L)Cl }]^{7}\right.$}

Sav-mutants were dissolved in phosphate buffer $(20 \mathrm{mM}, \mathrm{pH} 7)$ to a tetrameric concentration of $8 \mu \mathrm{M}$. The solution was added to a quartz cuvette $(2.4 \mathrm{ml})$ and treated with $0.3 \mathrm{ml}$ of a 2-(4-hydroxyphenylazo)benzoic acid solution (HABA, 9.6 $\mathrm{mM}$ in phosphate buffer $\mathrm{pH} 7)$. To this mixture was added stepwise $5 \mu \mathrm{L}$ of either a biotin solution $(0.96 \mathrm{mM}$ in phosphate buffer) or $1.7 \mu \mathrm{l}$ of a [Cp*Ir(biot- $p$-L)Cl] solution $(2.9 \mathrm{mM}$ in DMF), corresponding to 0.25 equivalents vs. Sav tetramer. The solution was mixed at each step by means of pipetting up and down. After 5 minutes, the absorbance at 506 nm was measured.

\section{Crystallographic protocol and resolution}

\section{Crystallization of $[$ Cp*Ir(Biot-p-L)CI] $\subset$ S112K Sav.}

Lyophilized Sav-S112K containing an N-terminal T7-tag (13 amino acids) was dissolved in dd- $\mathrm{H}_{2} \mathrm{O}$ to a concentration of $26 \mathrm{mg} / \mathrm{mL}$. In a hanging-drop set up, $5 \mu \mathrm{L}$ protein solution and $5 \mu \mathrm{L}$ crystallization buffer $(2.6 \mathrm{M}$ ammonium sulfate, 0.1 $\mathrm{M}$ sodium acetate, $\mathrm{pH} 4.0$ ) were mixed and equilibrated against a reservoir of $500 \mu \mathrm{L}$ crystallization buffer for three days at $20{ }^{\circ} \mathrm{C}$. To adjust the $\mathrm{pH}$ of the crystal close to a value used in the imine reduction experiment (pH 7.5) single Sav crystals were successively transferred into droplets containing $5 \mu \mathrm{L}$ water and $5 \mu \mathrm{L}$ crystallization buffer with pH 6.0, 7.0 and 8.0, and equilibration for about $30 \mathrm{~s}$ at each $\mathrm{pH}$. For the cofactor soaking, single crystals of apo- S112K Sav were transferred into a soaking solution, consisting of $9 \mu \mathrm{L}$ crystallization buffer $(\mathrm{pH}$ 8.0) and $1 \mu \mathrm{L} 10 \mathrm{mM}[\mathrm{Cp} * \operatorname{Ir}(\mathrm{Biot}-p$ $\mathrm{L}) \mathrm{Cl}$ ] in DMSO, and equilibrated in a hanging-drop set up for $1 \mathrm{~h}$ at $20^{\circ} \mathrm{C}$ before flash-freezing in liquid nitrogen.

\section{Diffraction Data Collection and Structure Solution.}

Diffraction data were collected at the Swiss Light Source beam line PXIII at a wavelength of $1.36246 \AA$ to a resolution of $2.5 \AA$. Data indexing, integration and scaling was carried out using programs iMOSFLM $^{8}$ and AIMLESS $^{9}$ of the CCP4 Suite (Table SI1). The structure was solved by molecular replacement with the program PHASE ${ }^{10}$ using PDB structure $2 \mathrm{QCB}^{11}$ as model devoid of any ligand and water molecules. The structure refinement was carried out with software REFMAC5 ${ }^{12}$ and PHENIX.REFINE ${ }^{13}$. COOT ${ }^{14}$ and PYMOL were used for the model building and the structure illustration respectively.

\section{Overall structure, biotin-binding site and cofactor localization.}

The molecular replacement procedure yielded one Sav monomer in the asymmetric unit. Probably due to their pronounced flexibility, residues 2-13 and 135-159 of the Sav monomer are not resolved; as observed in earlier Sav structures that crystallize in the same crystal form (e.g. PDB code 2QCB). Upon a single round of rigid body and full atomic refinement, residual electron density in the Fo-Fc map was encountered in the biotin-binding site and the neighboring vestibule that bridges two symmetry-related Sav monomers that constitute one half of the 222-symmetrical biological Sav tetramer (Figure SI1). Two cofactor conformations were modeled in the electron density. In close proximity to the imidazole sidechain of residue His127, strong residual electron density in the 2Fo-Fc map was detected that could not be modeled with a single water molecule. Similar to the structure of $[\mathrm{Cp} * \operatorname{Ir}($ Biot- $p$-L)Cl] $\subset \mathrm{S} 112 \mathrm{~A}$ Sav (PDB code 3PK2), this density was modeled with a single iridium atom which is believed to be a result of partial metal dissociation from the cofactor. The $\mathrm{N}^{\delta}$-His $127 \cdots \cdots$. Ir distance is $2.9 \AA$ and the metal occupancy was set to $30 \%$. Finally, a total of 21 water molecules were modeled in the structure.

\section{Docking Simulations: General Considerations}

Two different pairs of the $\left(R_{\mathrm{Ir}}\right)$ - and $\left(S_{\mathrm{Ir}}\right)$-enantiomers at the metal of the catalyst precursor were obtained through QM minimizations: one pair corresponded to the saturated form $([\mathrm{Cp} * \operatorname{Ir}(\operatorname{Biot}-p-\mathrm{L}) \mathrm{Cl}])$ of the cofactors while in the other the chlorine ligand was replaced by a lysine. All of them were performed within the Kohn-Sham approximation of Density Functional Theory (DFT) using the M06 functional ${ }^{15}$ as implemented in Gaussian09. ${ }^{16}$ The basis set Def2-TZVPP ${ }^{17}$ and its associated pseudo-potential were used for the iridium and the $6-31 \mathrm{G}^{* 18}$ for the rest of the atoms.

The minimized structures of the cofactors coordinated by a lysine were docked into a dimeric form of the [Cp* $\operatorname{Ir}(\operatorname{Biot}-p$ $\mathrm{L}) \mathrm{Cl}] \subset \mathrm{S} 112 \mathrm{~K}$ crystallographic structure incorporating the two neighbouring biotin-binding sites using the program GOLD (version 5.1) ${ }^{19}$ and the ChemScore scoring function. ${ }^{20,21}$ An inspection of all X-ray structures of artificial 
metalloenzymes ${ }^{11,22-25}$ based on the biotin-streptavidin technology reveals that the position of the biotin-moiety within Sav remains essentially invariant. Accordingly the biotin moiety of the cofactor was always kept within the biotin-binding pocket of each monomer up to the $\mathrm{N}_{\text {amide }}$ atom (Scheme 1) and a covalent restraint, available in GOLD, was applied using this same nitrogen as the anchoring atom. The aim of this step was to determine whether or not Lysine112 from the monomer A (Lys112 $\mathrm{A}$ ) was able to bind to the iridium, thus we used a docking procedure specifically designed to deal with the binding of inorganic compounds in proteins. ${ }^{26}$ We therefore replaced the lysine of the minimized structure for a hydrogen and replaced the iridium metal for a new atom-type designed as a hydrogen-bond donor in order to mimic the capacity of metal atoms to interact with Lewis bases (i.e. the nitrogen of the $\mathrm{RNH}_{2}$ group of the deprotonated Lys $112_{\mathrm{A}}$ ). This atom was set to have a tetrahedral geometry (as it is the one expected for the chelated form of the iridium) and all other parameters were adapted from the existing metal-ligand terms found in GOLD. No X-ray density for lysine 112 was observed in the Fo-Fc omit map, and the position of its side chain was only suggested upon modelling in the 2Fo-Fc map. Therefore, Lys 112 was allowed flexibility using the Dunbrack Rotameric library as implemented in GOLD during the docking experiments. ${ }^{27}$ The lowest-energy structure presenting an interaction between the pseudo-metal atom type and the $\mathrm{N} \zeta$ of Lys $112_{\mathrm{A}}$ was further refined through a QM/MM procedure using the two-layer $\mathrm{ONIOM}^{28}$ methodology as implemented in Gaussian $09^{16}$ and using the electronic embedding scheme. ${ }^{29}$ The catalyst moiety up to the first carbon of the biotin linker and Lys112 $\mathrm{A}$ up to $\mathrm{C}_{\alpha}$ were included in the high layer of the calculation (both carbons were also included in this layer). This QM region was treated using the same basis sets as in the previous QM calculations but the functional was switch to PBE. ${ }^{30,31}$ We changed the functional as we successfully used it on a previous study to represent the QM partition of this kind of artificial hydrogenases. ${ }^{32}$ The AMBER force field ${ }^{33}$ was used to represent the low layer, in which the whole cofactor as well as the surrounding residues Lys $112_{\mathrm{A}}$, Lys $112_{\mathrm{B}}$, Lys $121_{\mathrm{A}}$, Lys $121_{\mathrm{B}}$, Leu110 $0_{\mathrm{A}}$, Leu124 and Leu $124_{B}$ were allowed flexibility. The same QM/MM scheme was used to minimize the S112K Sav dimeric model presenting two different cofactors with a possible chelation by both Lys112. In this case, the flexible region was considered a sphere of $5 \AA$ around both cofactors while the QM region was unaltered.

The minimized forms of both enantiomers of the saturated cofactors were also docked into the truncated dimeric Sav unit using the same covalent docking approach. In this case we successively docked two different cofactors in a two-step procedure to determine if: i) there is a preference for a specific Ir configuration of [Cp*Ir(Biot- $p-\mathrm{L}) \mathrm{Cl}]$ cofactor towards binding, ii) whether two such cofactors can be accommodated in a dimer and iii) whether there is a configurational preference for the second binding event (Scheme 1).

In the first step, a single [Cp*Ir(Biot- $p-\mathrm{L}) \mathrm{Cl}]$ catalyst was docked in the dimer model of the Sav tetramer. The resulting structure was then used as a receptor to dock a second $[\mathrm{Cp} * \operatorname{Ir}(\operatorname{Biot}-p-\mathrm{L}) \mathrm{Cl}]$ moiety. The recently reported crystallographic structure of the $[\mathrm{Cp} * \operatorname{Ir}($ Biot- $p-\mathrm{L}) \mathrm{Cl}] \subset \mathrm{S} 112 \mathrm{~A}$ was used as the Sav receptor in the initial dockings for that mutant. ${ }^{24}$ In this case no flexibility was introduced during the docking simulation. The docking calculations of the $[\mathrm{Cp} * \operatorname{Ir}(\mathrm{Biot}-p-\mathrm{L}) \mathrm{Cl}] \subset$ S112K mutant were performed on an in silico mutated S112A receptor, allowing flexibility of the Lys112 amino acid of each monomer, showing an unclear position of both the iridium moiety and the Lys112 (in absence of the coordination with the iridium center) and the fact that the two receptors had identical geometries (with the exception of these two groups). Additionally, residues Lys $121_{\mathrm{A}, \mathrm{B}}$, Leu124 $4_{\mathrm{A}, \mathrm{B}}$, and Lys $112_{\mathrm{A}, \mathrm{B}}$ of each monomer and Leu110 of the corresponding monomer where the cofactor is being docked were also allowed to relax. All dockings were performed using the same covalent approach as in the previous docking simulations as well as the same Dunbrack Rotameric library to introduce the flexibility on selected residues. Docking of the substrate was performed on all the calculated cofactor $\subset$ Sav structures. Building on recent computations by Petr, experiments by Wills and additional calculations performed in our group on the ATH of imines, ${ }^{32,34,35}$ the protonated imine was used as a substrate for the docking. On those structures, the chlorine was replaced with a hydride to ensure consistency with the catalytic mechanism. The distance between the hydride and the iridium was set to $1.6 \AA$ as calculated using the same DFT approach as with the preparation with the $[\mathrm{Cp} * \operatorname{Ir}(\mathrm{Biot}-p$-L)Cl] moieties. A small harmonic distance restraint from $3.5 \AA$ to $2.5 \AA$ with a $5 \mathrm{~kJ} \cdot \mathrm{mol}^{-1}$ spring constant was applied between the reactive prochiral carbon of the substrate and the hydride. This restraint was applied to probe whether or not the substrate could interact in an orientation compatible with the transfer of the hydride from the metal to the carbon. All structures were prepared as specified in the GOLD manual using the UCSF Chimera interface. ${ }^{36}$ 
Table SI1. Data collection and refinement statistics of crystal structure $[\mathrm{Cp} * \operatorname{Ir}($ Biot $-p-\mathrm{L}) \mathrm{Cl}] \subset \mathrm{S} 112 \mathrm{~K}$ Sav.

\begin{tabular}{|c|c|}
\hline \multicolumn{2}{|c|}{ Data Collection } \\
\hline Resolution $(\AA)$ & $25.4-2.5$ \\
\hline Space Group & $\mathrm{I} 4_{1} 22$ \\
\hline Cell Dimensions $(\AA)$ & $\mathrm{a}=57.6 \mathrm{~b}=57.6 \mathrm{c}=183.3$ \\
\hline Rmerge $(\%)$ & $22.1(22.0)^{*}$ \\
\hline No. unique reflections & 4971 \\
\hline Multiplicity & $7.5(1.4)$ \\
\hline Completeness & $86.7(27.8)$ \\
\hline I/ $($ II) & $6.1(1.5)$ \\
\hline \multicolumn{2}{|c|}{ Refinement } \\
\hline Resolution $(\AA)$ & $25.4-2.5$ \\
\hline Rwork/Rfree $(\%)$ & $19.8 / 24.0$ \\
\hline \multicolumn{2}{|c|}{ B-factors $\left(\AA^{2}\right)$} \\
\hline Protein & 17 \\
{$[$ Cp*Ir(Biot-p-L)Cl] } & 26 \\
Water & 17 \\
\hline \multicolumn{2}{|c|}{ RMS deviations } \\
\hline Bond angles (o) & 1.4 \\
\hline
\end{tabular}

* Values in parentheses are for highest-resolution shell $2.6-2.5 \AA$.

Table SI2. Breakdown of the docking energy terms

\begin{tabular}{|c|c|c|c|c|c|c|c|c|}
\hline Host Protein & Cofactor & Score* & $\Delta \mathbf{G}^{+}$ & $\mathrm{S}_{\mathrm{hbond}}{ }^{*}$ & $S_{\text {lipo }} *$ & $\mathbf{H}_{\text {rot }}$ * & $\Delta \mathbf{E}_{\text {clash }} *$ & $\Delta \mathrm{E}_{\mathrm{int}}{ }^{*}$ \\
\hline \multirow[t]{2}{*}{ S112A } & $S_{\text {Ir }}$ & 44.4 & -55.0 & 5.3 & 314.6 & 2.0 & 0.4 & 10.2 \\
\hline & $R_{\mathrm{Ir}}$ & 43.2 & $\begin{array}{l}-50.4 \\
\end{array}$ & 4.0 & 314.0 & 2.0 & 0.5 & 6.8 \\
\hline \multirow[t]{2}{*}{$\mathrm{S} 112 \mathrm{~K}$} & $S_{\text {Ir }}$ & 51.5 & -60.0 & 6.0 & 336.2 & 2.0 & 0.7 & 7.8 \\
\hline & $R_{\mathrm{Ir}}$ & 58.6 & -66.8 & 7.1 & 365.1 & 2.0 & 0.3 & 7.9 \\
\hline \multirow{2}{*}{$\begin{array}{c}S_{\mathrm{Ir}}-[\mathrm{Cp} * \mathrm{Ir}(\text { Biot-p- } \\
\mathrm{L}) \mathrm{Cl}] \subset \mathrm{S} 112 \mathrm{~A}\end{array}$} & $S_{\text {Ir }}$ & 43.0 & -52.2 & 5.4 & 306.7 & 2.0 & 1.5 & 9.6 \\
\hline & $R_{\mathrm{Ir}}$ & 43.9 & -51.8 & 4.2 & 320.0 & 2.0 & 0.3 & 7.6 \\
\hline \multirow{2}{*}{$\begin{array}{c}R_{\mathrm{Ir}}-[\mathrm{Cp} * \mathrm{Ir}(\text { Biot-p- } \\
\mathrm{L}) \mathrm{Cl}] \subset \mathrm{S} 112 \mathrm{~K}\end{array}$} & $S_{\text {Ir }}$ & 44.4 & -52.7 & 3.7 & 341.6 & 2.0 & 0.4 & 7.8 \\
\hline & $R_{\mathrm{Ir}}$ & 42.5 & -52.2 & 4.3 & 319.1 & 2.0 & 0.5 & 9.2 \\
\hline
\end{tabular}

* Values dimensionless ${ }^{+}$Values in $\mathrm{kJ} \cdot \mathrm{mol}^{-1}$ 
a)

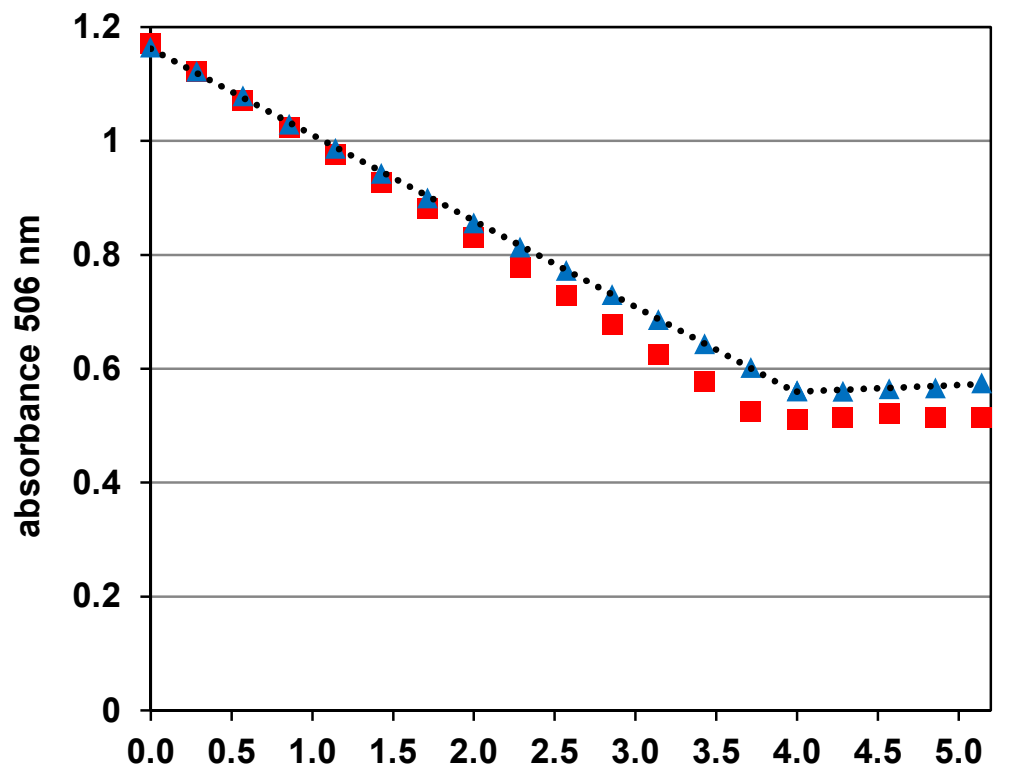

b)

[Ir] vs. Sav S112A

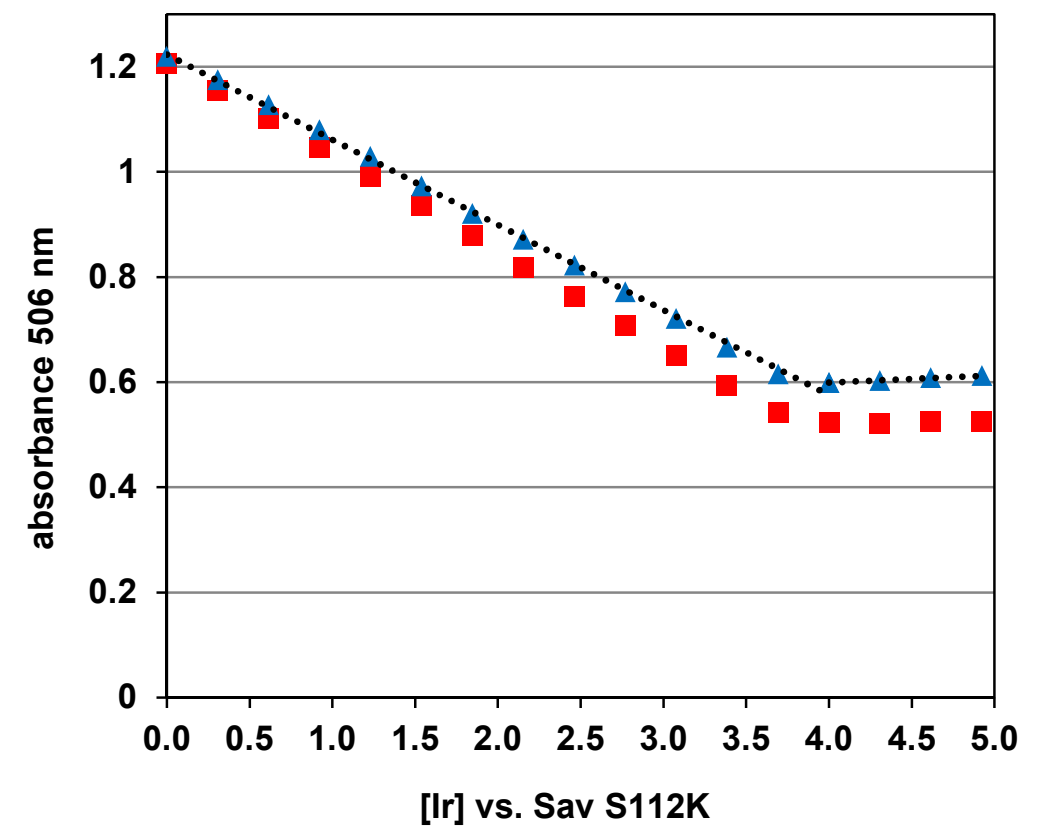

Figure SI1 HABA-displacement titration assay by $[\mathrm{Cp} * \operatorname{Ir}($ biot- $p-\mathrm{L}) \mathrm{CI}](\Delta$, blue triangles) and biotin $(\square$, red squares) in the presence of Sav S112 $A$ a) and Sav S112K b). The linear decrease (dotted line) of the absorbance at $\lambda_{\max } 506 \mathrm{~nm}$ (caused by the quantitative displacement of HABA $\subset$ Sav by [Cp* $\operatorname{Ir}($ biot- $p$-L)Cl]) precludes the determination of a precise dissociation constant but sets a lower limit at $K_{\mathrm{a}}>10^{9} \mathrm{M}^{-1}$. The molecular weight of Sav was adjusted to take into consideration the presence of residual salts. ${ }^{7}$ 

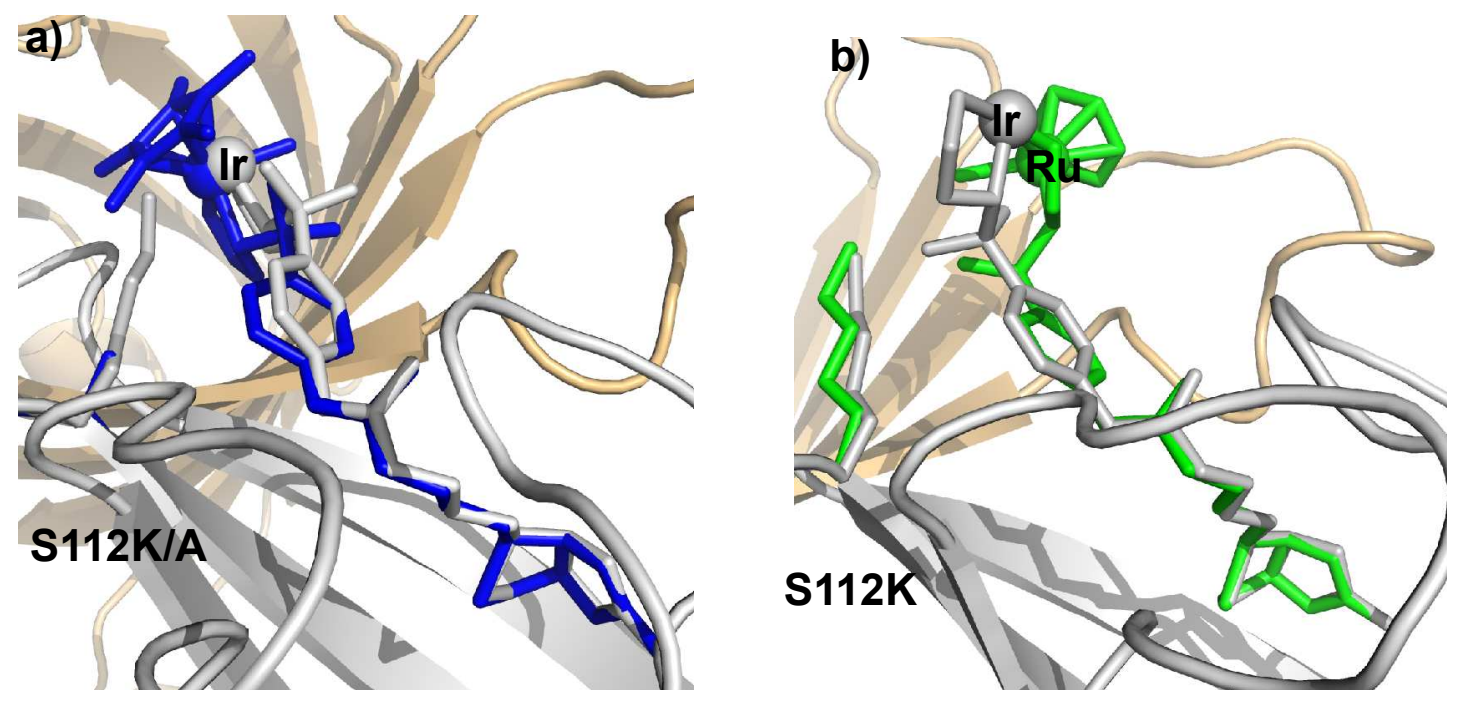

Figure SI2. Close-up view of the cofactor-binding site in the crystal structure of complex $[\mathrm{Cp} * \operatorname{Ir}(\mathrm{Biot}-p-\mathrm{L}) \mathrm{Cl}] \subset \mathrm{S} 112 \mathrm{~K}$ Sav. The cofactor conformations A a) and B b) (grey color) are superimposed with the cofactors of structures [Cp* $\operatorname{Ir}(\mathrm{Biot}-p-\mathrm{L}) \mathrm{Cl}] \subset \mathrm{S} 112 \mathrm{~A} \mathrm{Sav}$ (blue color, PDB code 3PK2) and $\left[\left(\eta^{6}\right.\right.$-benzene)Ru(Biot- $p$-L)Cl] $\subset \mathrm{S} 112 \mathrm{~K}$ Sav (green color, PDB code 2QCB), respectively, Only one Sav dimer is shown for clarity. 


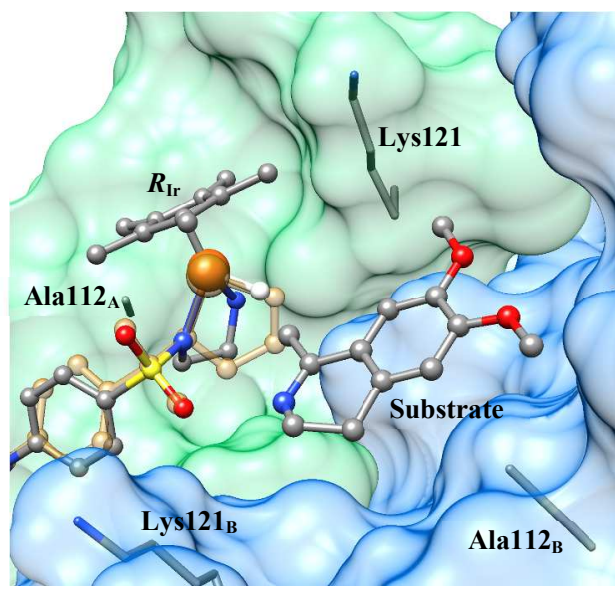

(a)

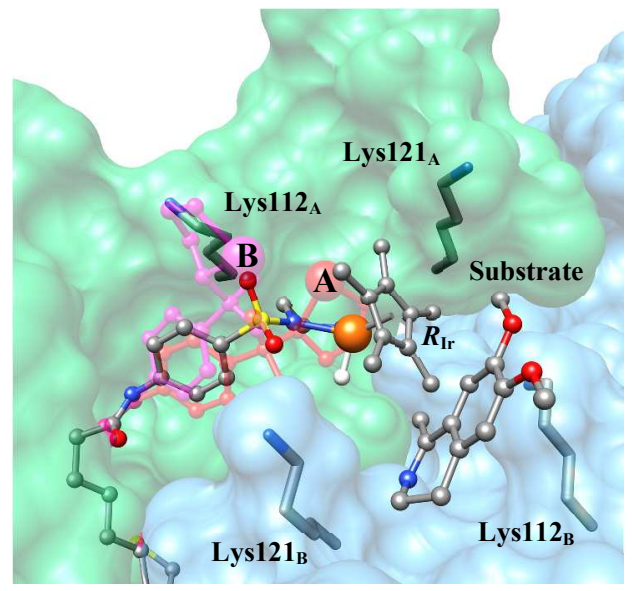

(c)

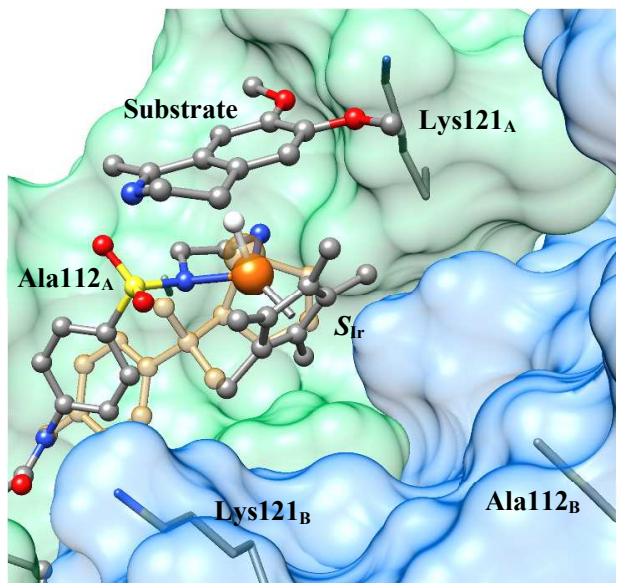

(b)

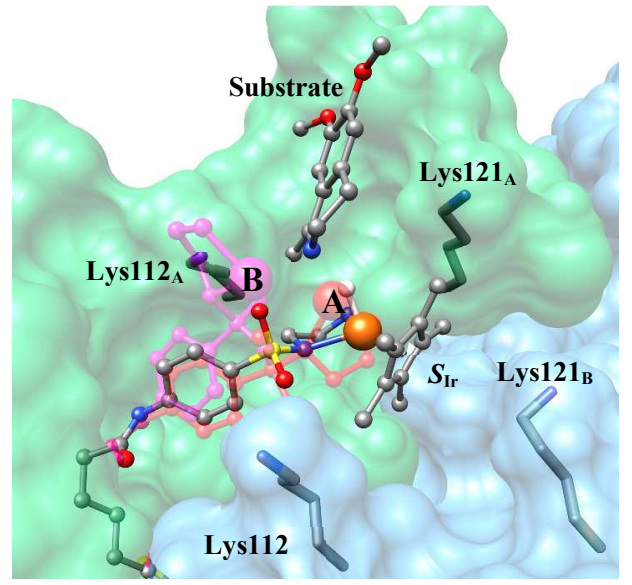

(d)

Figure SI3. Close-up view of the different models of the $[\mathrm{Cp} * \operatorname{Ir}($ Biot $-p-\mathrm{L}) \mathrm{H}] \subset \mathrm{S} 112 \mathrm{X}$ ATHases obtained in the docking simulations, including the docked imine 1: a) $\left(R_{\mathrm{Ir}}\right)-\mathrm{Ir}, \mathrm{X}=\mathrm{A}$, b) $\left.\left.\left(S_{\mathrm{Ir}}\right)-\mathrm{Ir}, \mathrm{X}=\mathrm{A}, \mathbf{c}\right)\left(R_{\mathrm{Ir}}\right)-\mathrm{Ir}, \mathrm{X}=\mathrm{K}, \mathbf{d}\right)\left(S_{\mathrm{Ir}}\right)-\mathrm{Ir}, \mathrm{X}=\mathrm{K}$. Sav is displayed as cartoon with relevant aminoacids highlighted as stick. Both the synthetic cofactor and the substrate are represented as ball and stick. The X-ray determined position of the cofactor in the $\mathrm{Cp} * \operatorname{Ir}($ Biot $-p-\mathrm{L}) \mathrm{Cl}] \subset \mathrm{S} 112 \mathrm{~A}$ and $\mathrm{Cp} * \operatorname{Ir}($ Biot- $p-\mathrm{L}) \mathrm{Cl}] \subset \mathrm{S} 112 \mathrm{~K}$ (including both conformation $\mathrm{A}$ and B) ATHases are shown in yellow, red and pink ghost colors respectively. 


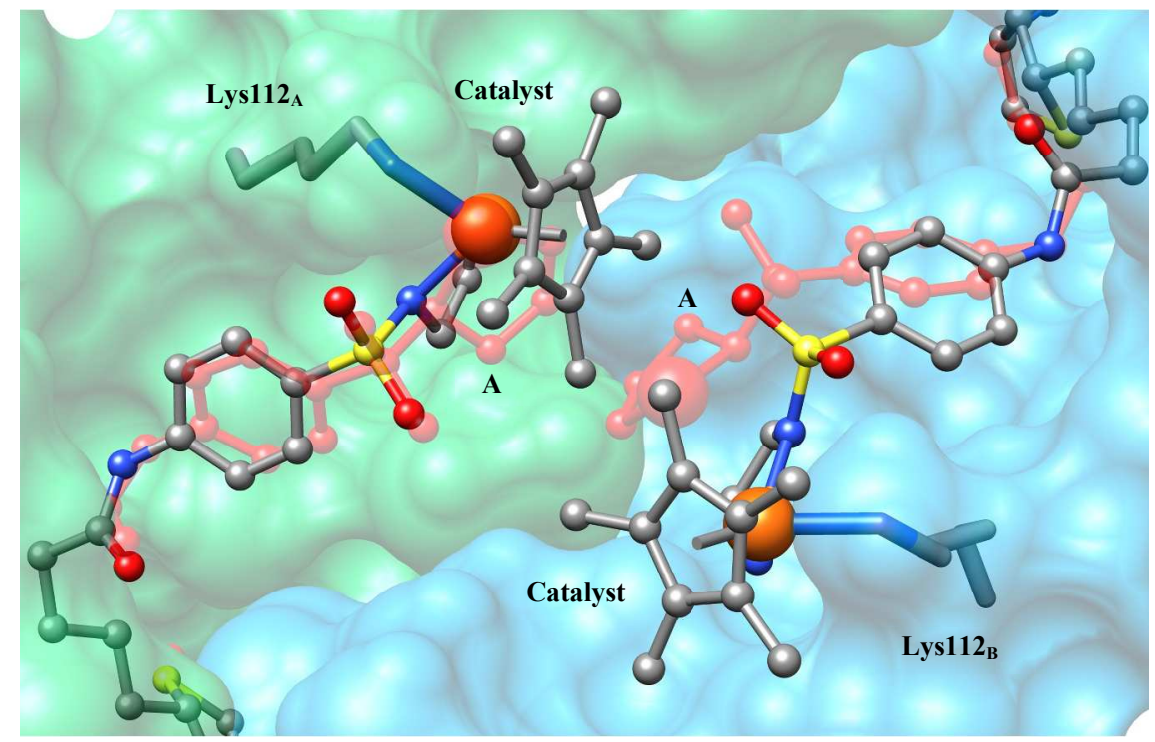

Figure SI4. Depiction of the doubly-occupied S112K Sav $1 / 2$ ATHase with both cofactors coordinated by Lys112. Monomer A and Monomer blue are colored in green and blue respectively. The cofactors are represented in ball and stick, while the protein residues are in stick. The A orientation of the homogeneous catalyst as found in the X-ray structure is depicted in ghost red color. 


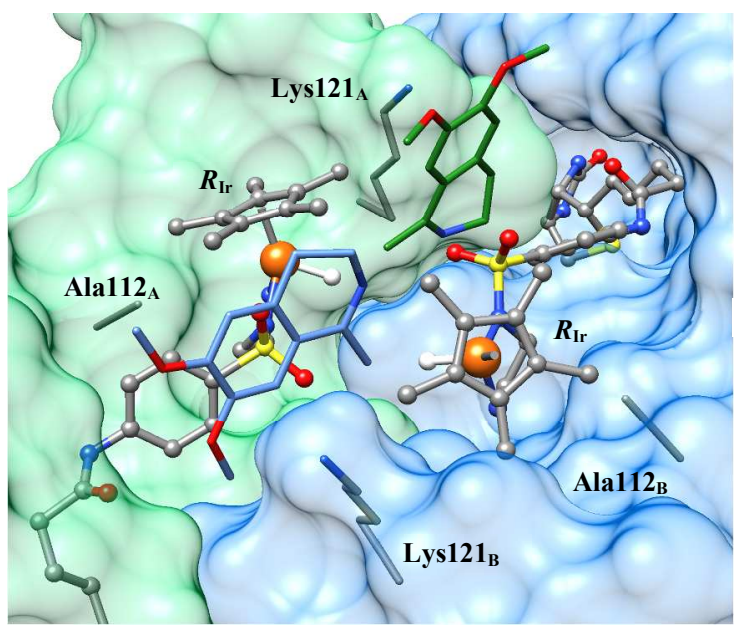

(a)

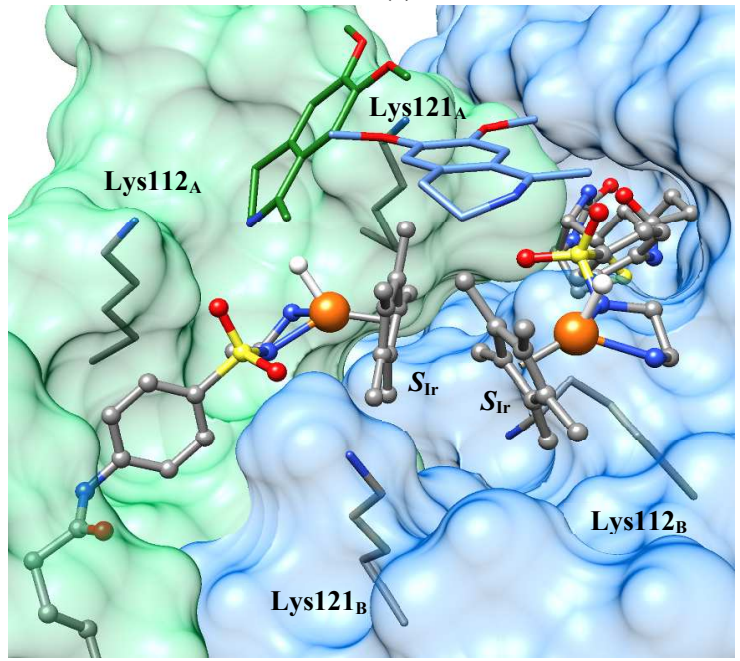

(c)

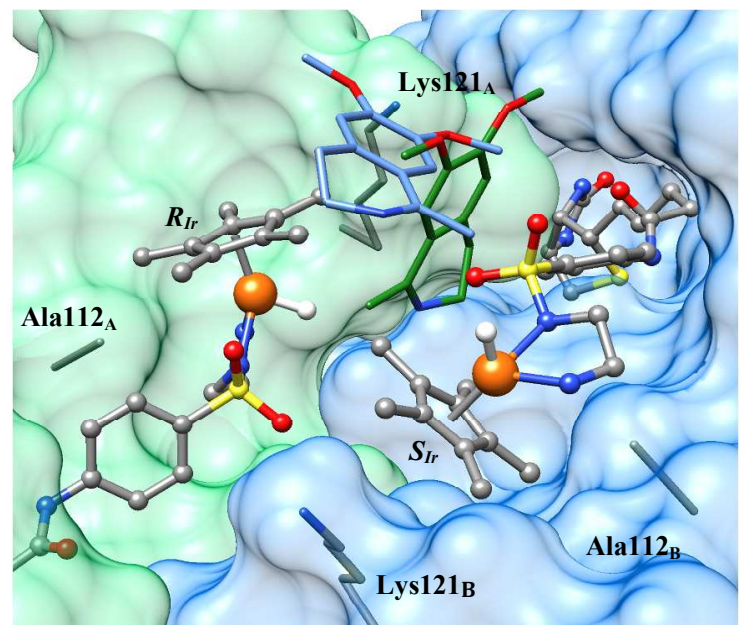

(b)

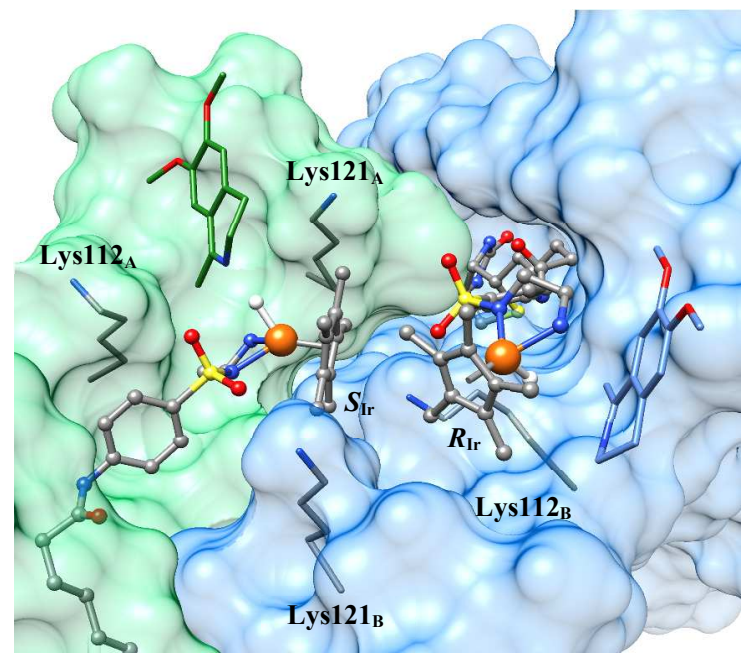

(d)

Figure SI5. Representation of the models of a fully-loaded dimer of the Sav tetramer. The cofactors are represented in ball and stick, and the nearby residues in stick. Monomer A is depicted in green, monomer B in blue. The chlorides have been substituted for the corresponding hydride to give consistency with the docking of the substrate. Top: Mutant S112A with two $\left(R_{\mathrm{Ir}}\right)-[\mathrm{Cp} * \operatorname{Ir}(\mathrm{Biot}-p$ - $\mathrm{L}) \mathrm{H}]$ cofactors $(\mathbf{a})$ or one $\left(S_{\mathrm{Ir}}\right)-$ one $\left(R_{\mathrm{Ir}}\right)-[\mathrm{Cp} * \mathrm{Ir}(\operatorname{Biot}-p-\mathrm{L}) \mathrm{H}](\mathbf{b})$. Bottom: Mutant $\mathrm{S} 112 \mathrm{~K}$ with two $\left(S_{\mathrm{Ir}}\right)-[\mathrm{Cp} * \operatorname{Ir}(\operatorname{Biot}-p-\mathrm{L}) \mathrm{H}](\mathbf{c})$ or one $\left(R_{\mathrm{Ir}}\right)-$ one $\left(S_{\mathrm{Ir}}\right)-[\mathrm{Cp} * \mathrm{Ir}($ Biot- $p$-L)H] moieties $(\mathbf{d})$. Green substrates were docked adding a restraint with the catalyst in monomer A, while in the blue ones it was added with the catalyst in monomer B. 


\section{References}

(1) Köhler, V.; Mao, J.; Heinisch, T.; Pordea, A.; Sardo, A.; Wilson, Y. M.; Knörr, L.; Creus, M.; Prost, J.-C.; Schirmer, T.; Ward, T. R. Angew. Chemie Int. Ed. 2011, 123, 11055-11058.

(2) Galizia, A.; de Lalla, C.; Nardone, E.; Santambrogio, P.; Brandazza, A.; Sidoli, A.; Arosio, P. Protein Expr. Purif. 1998, 14, 192-196.

(3) Wilson, Y. M.; Dürrenberger, M.; Ward, T. R. In Engineering Handbook, Volume III; Wiley-VCH: Weinheim, 2012.

(4) Kada, G.; Kaiser, K.; Falk, H.; Gruber, H. J. Biochim. Biophys. Acta 1999, 1427, 44-48.

(5) Michaelis, L.; Menten, M. M. L. Biochem. Z. 1913, 49, 333-369.

(6) Haldane, J. Enzymes; Longmand, Green and Co: New York, 1930.

(7) Skander, M.; Humbert, N.; Collot, J.; Gradinaru, J.; Klein, G.; Loosli, A.; Sauser, J.; Zocchi, A.; Gilardoni, F.; Ward, T. R. J. Am. Chem. Soc. 2004, 126, 14411-14418.

(8) Battye, T. G. G.; Kontogiannis, L.; Johnson, O.; Powell, H. R.; Leslie, A. G. W. Acta Crystallogr. D 2011, 67, $271-281$.

(9) Evans, P. Acta Crystallogr. D 2011, 67, 282-292.

(10) McCoy, A. J.; Grosse-Kuntsleve, R. W.; Adams, P. D.; D., W. M.; Storoni, C. L.; Read, R. J. J. App. Cryst. 2007, 40, 658-674.

(11) Creus, M.; Pordea, A.; Rossel, T.; Sardo, A.; Letondor, C.; Ivanova, A.; Letrong, I.; Stenkamp, R. E.; Ward, T. R. Angew. Chemie Int. Ed. 2008, 47, 1400-1404.

(12) Murshudov, G. N.; Vagin, A. A.; Dodson, E. J. Acta Cryst. D. 1997, 53, 240-255.

(13) Adams, P. D.; Afonine, P. V.; Bunkóczi, G.; Chen, V. B.; Davis, I. W.; Echols, N.; Headd, J. J.; Hung, L.-W.; Kapral, G. J.; Grosse-Kuntsleve, R. W.; McCoy, A. J.; Moriarty, N. W.; Oeffned, R.; Read, R. J.; Richardson, D. C.; Richardson, J. S.; Terwilliger, T. C.; Zwart, P. H. Acta Crystallogr. D 2010, 66, 213-221.

(14) Emsley, P.; Cowtan, K. Acta Crystallogr. D 2004, 60, 2126-2132.

(15) Zhao, Y.; Truhlar, D. G. J. Chem. Phys. 2006, 125, 1-18.

(16) Frisch, M. J.; Trucks, G. W.; Schlegel, H. B.; Scuseria, G. E.; Robb, M. A.; Cheeseman, J. R.; Scalmani, G.; Barone, V.; Mennucci, B.; Petersson, G. A.; Nakatsuji, H.; Caricato, M.; Li, X.; Hratchian, H. P.; Izmaylov, A. F.; Bloino, J.; Zheng, G.; Sonnenberg, J. L.; Hada, M.; Ehara, M.; Toyota, K.; Fukuda, R.; Hasegawa, J.; Ishida, M.; Nakajima, T.; Honda, Y.; Kitao, O.; Nakai, H.; Vreven, T.; Montgomery, J. A.; Jr.; Peralta, J. E.; Ogliaro, F.; Bearpark, M.; Heyd, J. J.; Brothers, E.; Kudin, K. N.; Staroverov, V. N.; Kobayashi, R.; Normand, J.; Raghavachari, K.; Rendell, A.; Burant, J. C.; Iyengar, S. S.; Tomasi, J.; Cossi, M.; Rega, N.; Millam, J. M.; Klene, M.; Knox, J. E.; Cross, J. B.; Bakken, V.; Adamo, C.; Jaramillo, J.; Gomperts, R.; Stratmann, R. E.; Yazyev, O.; Austin, A. J.; Cammi, R.; Pomelli, C.; Ochterski, J. W.; Martin, R. L.; Morokuma, K.; Zakrzewski, V. G.; Voth, G. A.; Salvador, P.; Dannenberg, J. J.; Dapprich, S.; Daniels, A. D.; Farkas, Ö.; Foresman, J. B.; Ortiz, J. V; Cioslowski, J.; Fox, D. J. Gaussian 09, Revision A.1, 2009.

(17) Weigend, F.; Ahlrichs, R. Phys. Chem. Chem. Phys. 2005, 7, 3297-3305.

(18) Hehre, W. J. J. Chem. Phys. 1972, 56, 2257-2261.

(19) Verdonk, M. L.; Cole, J. C.; Hartshorn, M. J.; Murray, C. W.; Taylor, R. D. PROTEINS Struct. Funct. Bioinforma. 2003, 52 , 609-623.

(20) Eldridge, M. D.; Murray, C. W.; Auton, T. R.; Paolini, G. V; Mee, R. P. J. Comput. Aided. Mol. Des. 1997, 11, $425-445$.

(21) Baxter, C. a; Murray, C. W.; Clark, D. E.; Westhead, D. R.; Eldridge, M. D. Proteins 1998, 33, 367-382.

(22) Zimbron, J. M.; Sardo, A.; Heinisch, T.; Wohlschlager, T.; Gradinaru, J.; Massa, C.; Schirmer, T.; Creus, M.; Ward, T. R. Chem. An Eur. J. 2010, 16, 12883-12889.

(23) Zimbron, J. M.; Heinisch, T.; Schmid, M.; Hamels, D.; Nogueira, E. S.; Schirmer, T.; Ward, T. R. J. Am. Chem. Soc. 2013, $135,5384-5388$.

(24) Dürrenberger, M.; Heinisch, T.; Wilson, Y. M.; Rossel, T.; Nogueira, E.; Knörr, L.; Mutschler, A.; Kersten, K.; Zimbron, M. J.; Pierron, J.; Schirmer, T.; Ward, T. R. Angew. Chemie Int. Ed. 2011, 50, 3026-3029.

(25) Pierron, J.; Malan, C.; Creus, M.; Gradinaru, J.; Hafner, I.; Ivanova, A.; Sardo, A.; Ward, T. R. Angew. Chemie Int. Ed. 2008, 47, 701-705.

(26) Muñoz Robles, V.; Ortega-Carrasco, E.; Fuentes, E. G.; Lledós, A.; Maréchal, J.-D. Faraday Discuss. 2011, $148,137$.

(27) Chase, F.; Avenue, B. Curr. Opin. Struct. Biol. 2002, 12, 431-440.

(28) Dapprich, S.; Komáromi, I.; Byun, K. S.; Morokuma, K.; Frisch, M. J. J. Mol. Struct. 1999, 461-462, 1-21.

(29) Bakowies, D.; Thiel, W. J. Phys. Chem. 1996, 3654, 10580-10594.

(30) Perdew, J. P.; Ernzerhof, M.; Burke, K. J. Chem. Phys. 1996, 105, 9982-9985.

(31) Perdew, J.; Burke, K.; Ernzerhof, M. Phys. Rev. Lett. 1996, 77, 3865-3868.

(32) Muñoz Robles, V.; Vidossich, P.; Lledós, A.; Ward, T. R.; Maréchal, J.-D. ACS Catal. 2014, 4, 833-842.

(33) Cornell, W. D.; Cieplak, P.; Bayly, C. I.; Gould, I. R.; Merz, K. M.; Ferguson, D. M.; Spellmeyer, D. C.; Fox, T.; Caldwell, J. W.; Kollman, P. a. J. Am. Chem. Soc. 1995, 117, 5179-5197.

(34) Jiří Václavík, Marek Kuzma, J. P.; Kačer, P. Organometallics 2011, 30, 4822-4829.

(35) Martins, J. E. D.; Clarkson, G. J.; Wills, M. Org. Lett. 2009, 11, 847-850.

(36) Pettersen, E. F.; Goddard, T. D.; Huang, C. C.; Couch, G. S.; Greenblatt, D. M.; Meng, E. C.; Ferrin, T. E. J. Comput. Chem. 2004, 25, 1605-1612. 